\title{
The Judiciary, Diversity, and Justice For All $\dagger$
}

\section{Edward M. Chen $\ddagger$}

I am honored to be recognized by such a prestigious institution as the California Law Review ("CLR"). The honor flows not only from the fact that CLR is such an important part of my alma mater, but also because it played such an important role in my development as a lawyer. CLR helped me to sharpen and refine what I consider the most important skills in the legal profession - thorough legal research, sound legal analysis, and clear and organized writing. Most cases are won or lost on the papers.

At the same time, we the members of CLR produced, and continue to produce, a journal of outstanding quality. In this way, CLR also speaks to the power and effectiveness of students acting independently of faculty supervision and without any outside help. ${ }^{1}$ I marvel at students' ability to complete the countless tasks necessary to organize and publish high-quality journals such as CLR-all in their "spare time."

I am equally honored to have this Speech published in the Asian Law Journal ("ALJ"). ALJ's inaugural issue included an article copublished with CLR in which Professor Robert Chang discussed the growing number of Asian Pacific American legal scholars who were bringing new voices to academia. ${ }^{2}$ How appropriate, then, that for ALJ's ten-year anniversary issue I have an opportunity to express my views on the need for racial and ethnic diversity in the judiciary.

Copyright (C) 2003 Califormia Law Review, Inc. $\odot 2003$ Asian Law Journal, Inc. California Law Review, Inc. (CLR) is a California nonprofit corporation. CLR and the authors are solely responsible for the content of their publications.

$\dagger \quad$ This Speech was originally presented at the Califormia Law Review's annual banquet in April 2002, which honored Judge Chen as the California Law Review's 2002 Alumnus of the Year. Asian Law Journal will copublish this revised Speech as part of its ten-year anniversary issue, 10 AsIAN L.J. 127 (2003).

$\ddagger \quad$ Magistrate Judgc, United States District Court, Northern District of California. Staff Attomey, ACLU Foundation of Northern California, 1985-2001. J.D., School of Law, University of California, Berkeley (Boalt Hall), 1979. I want to express my appreciation to my law clerks Edwin Prather and Bill Kidder, as well as my extern Helen Paik, for their invaluable research and editing assistance. I also want to thank my family, Janet, Tara, and Luke, for their love and support.

1. In virtually every other academic discipline, the key publications are controlled and edited by faculty members. See Roger C. Cramton, "The Most Remarkable Institution": The American Law Review, 36 J. Legal Educ. I, I (I986).

2. Robert S. Chang, Toward an Asian American Legal Scholarship: Critical Race Theory, PostStructuralism, and Narrative Space, 81 CaLIF. L. Rev. I24I (1993), I Asian L.J. 1 (1993). 
While I am honored to be chosen Alumnus of the Year by CLR, I wonder, however, why me? It cannot be because I am the first Asian Pacific American on the federal bench for the Northern District of California. There are many other Asian Pacific American jurists who graduated from Boalt and went on to blaze far more adventurous and difficult trails to the judiciary bench before me. ${ }^{3}$ I have concluded that I was chosen because I am the only alumnus to join the bench directly after sixteen years of service with such a subversive organization as the American Civil Liberties Union ("ACLU”)!

Of course, this is not to disregard the experience of being the first Asian Pacific American on the federal bench for the Northern District of California. When I am asked what it is like to hold this position, I explain that there are a number of advantages. First, there is no one with whom I can be confused, at least while I am wearing a robe. Second, it is easy to organize Asian Pacific American jurists. I was able to organize the Asian Pacific American Federal Judges Association of the Northern District of California within a short time. Not only was I elected president, I was also elected vice prcsident, secretary, treasurer, and director!

Seriously, though, the appointment of the first Asian Pacific American to the federal bench for the Northern District of California is noteworthy, given the historical and geographical centrality this district has played in the lives of Asian Pacific Americans. The San Franeisco Bay Area has long been the point of entry for millions of Asian immigrants, and it has served as the home to numerous ethnic communities. It is no coincidence that landmark cases such as Yick Wo v. Hopkins, ${ }^{4}$ Korematsu v. United States, ${ }^{5}$ and Lau v. Nichols ${ }^{6}$ originated in this district. And yet until my appointment last year, there had never been an Asian Pacific American judicial officer on this bench in its 150 -year history.

3. For example, the Honorable Harry W. Low (retired), Boalt Hall class of 1955, served as the Presiding Justice of the California Court of Appeal in San Francisco. The Honorable Ken M. Kawaichi, class of 1966, has been an Alameda County Superior Court judge for many years. The Honorable Anthony W. Ishii, class of 1973, was appointed to the Eastern District of California in 1997 after previously serving as a state court judge. Therc are likely others that 1 am missing.

4. 118 U.S. 356 (1886).

5. 323 U.S. 214 (1944). I should disclose that in the early 1980s I worked on behalf of Fred Korematsu's coram nobis petition, which culminated in Korematsu v. United States, 584 F. Supp. 1406 (N.D. Cal. 1984) (vacating Korematsu's conviction and finding a manifest injustice because the U.S. government deliberately provided the Supreme Court with misleading information regarding the national security threat posed by Japanesc Americans during World War 11). For background on the original Korematsu case and the subsequent coram nobis petition, see generally Eric K. Yamamoto ET al., Race, Rights and Reparation: LAW and the JaPANESE American InTERnment (2001); Eric K. Yamamoto, Korematsu Revisited-Correcting the Injustice of Extraordinary Government Excess and Lax Judicial Review: Time for a Better Accommodation of National Security Concerns and Civil Liberties, 26 Santa Clara L. Rev, 1 (1986); Peter Irons, Justice at War (1983).

6. 414 U.S. 563 (1974). 
The fact that I am the first Asian Pacific American to be appointed to this bench (there is still no Asian Pacific American Article III judge on this court) says more about the appalling lack of diversity on the bench than it does about my personal credentials. While a great deal of progress has been made since the Civil Rights Movement thirty-five years ago, minorities, including Asian Pacific Americans, remain vastly underrepresented in the legal profession, especially in the judiciary. There currently is no Latina/o judge — either magistrate judge or district judge-in the Northern District of California. It was not until last year that one of my Boalt classmates, Fernando Olguin, was appointed as the first Latino magistrate judge in the Central District of California. It was not until last year that the first female Asian Pacific American magistrate judge, Jennifer Lum, was appointed to that bench as well.

National statistics reveal the lack of judges of color within the federal judiciary: Of the nearly I,600 active federal judges (including Article III judges, part- and full-time magistrate judges, bankruptcy judges, and court of claims judges) as of September 30, 200I, 7.2\% were African American, $4.0 \%$ were Latina/o, $0.8 \%$ were Asian American, and $0.1 \%$ were Native American. ${ }^{7}$ None were Pacific Islanders. ${ }^{8}$ Among minority judges, women of color were substantially underrepresented. ${ }^{9}$ In contrast, according to the 2000 census, African Americans were $12.3 \%$ of the U.S. population, Latinas/os were $12.5 \%$, Asian Pacific Americans were 3.7\%, and Native Americans were $0.9 \% .^{10}$

Of the 579 active district court judges nationwide, there are only five Asian Pacific Americans, including only one outside of California and Hawaii (Judge Denny Chin of the Southern District of New York). ${ }^{11}$ There are no Native American district court judges in the United States. ${ }^{12}$ There are a total of nineteen active judges of color at the appellate level,

7. Employee Relations Office, admin. Office U.S. Cts., Judiciary Fair Employment Practices AnN. Rep.: Fiscal Year 200I, 6, 32 tbl.B-1 (2002) [hereinafter Fair Employment PRACTICEs]. These figures combine Article 111, magistrate, bankruptcy, and court of claims judges. The total number of federal judges includes sixty-eight judges who declined to state their race and ethnicity. Id. at 32 tbl. B-1.

8. Id. at 32 tbl.B-1.

9. aba Comm. on Racial and Ethnic Diversity in the Profession, Miles to Go 2000: Progress of Minorities in the Legal Profession 20 tbl.44 (2000) [hereinafter Miles to Go 2000] (reporting that in 1999, 87 of 109 (or $80 \%$ ) of minority federal district court judges were men).

10. U.S. Census Bureau, Population by Race and Hispanic Origin for the United STATES: 2000, at $3 \mathrm{tbl.1}$, available at http://www.census.gov/prod $/ 2001 \mathrm{pubs} / \mathrm{c} 2 \mathrm{kbr} 01-1 . \mathrm{pdf}$ (last visited Apr. 1, 2003). In the text, 1 combined data for Asian Americans (3.6\%) with that of Native Hawaiians and other Pacific Islanders ( $0.1 \%)$. Id. Americans who identify as having two or more races compose $2.4 \%$. Id.

11. Fair Employment Practices, supra note 7, at 32 tbl.B-1.

12. Id. 
including one Asian Pacific American. ${ }^{13}$ Only $22.6 \%$ of active judges are women. ${ }^{14}$

One particularly troubling point is that the ranks of magistrate judges and bankruptcy judges, who are selected by the district courts and appellate courts, remain lcss diverse than Article III judges, who are appointed by the president with the advice and consent of the Senate and are thus not subject to customary hiring practices over which a single decision-making body has control. ${ }^{15}$ For instance, as of September 2001, of 539 magistrate judges, only $4.6 \%$ were African American, 3.7\% Latina/o, I.2\% Asian American, and $0.2 \%$ Native American. ${ }^{16}$ There were no reported Pacific Islander magistrate judges. ${ }^{17}$ Out of 328 bankruptcy judges, $4.9 \%$ were judges of color. ${ }^{18}$

Diversity on the bench in California state courts is equally discouraging. ${ }^{19}$ Although the percentage of minorities within the California bar has nearly doubled since 1991, their numbers continue to lag considerably when compared with the general population. ${ }^{20}$ Peoplc of color constitute nearly $54 \%$ of the California population but only $17 \%$ of the bar. ${ }^{21}$ Latinas/os make up more than a third of California's population, but only $3.7 \%$ of the bar..$^{22}$ African Americans constitute $6.4 \%$ of California's population, but only $2.4 \%$ of the bar. ${ }^{23}$ Asian Pacific Americans make up $11 \%$ of California's population, but only $6 \%$ of the bar. ${ }^{24}$ Moreover, according to a report by the director of bar admissions, unless law school numbers change dramatically, the California bar will still be disproportionately

\footnotetext{
13. Id.

14. Id. at 6 .

15. Id. at 32 tbl.B-l.

16. Id. at 6 . This includes 473 full-time and 66 part-time magistrate judges. $I d$. at 32 tbl.B-1.

17. Id. at 32 tbl.B-1.

18. Id.
}

19. Final Report of the Cal. Jud. Council advisory Comm. on Racial and Ethnic Bias IN THE CTS. 126 (1997) (reporting a 1993 Judicial Council survey finding that $89.3 \%$ of California superior court judges are White (including $77.3 \%$ White men), with $4 \%$ African American, $4.3 \%$ Latina/o, 2.3\% Asian Pacific American, and zero Native Americans). Research attorneys at California's Center for Judieial Education and Research and the California Judges Association and a professor on this committee confirmed that more current data have not been collected. More data on the recent racial and ethnic composition of judges appointed by the past four California governors wcre recently reported, but this is not an accurate measure of diversity in the California bench as a whole. Of 2,904 judges appointed by Governors Davis, Wilson, Deukmejian, and Brown, 201 (6.9\%) were Latina/o, 192 (6.6\%) were African American, and 131 (4.5\%) were Asian Pacific American. Harriet Change, Davis shaking up state judgeships-Gays, women, other minorities tapped for bench, S.F. CHRON., Mar. 21, 2003 , at Al.

20. See Survey Finds Bar Makeup Is Shifting, but Slowly, CAL. ST. B.J., Nov. 2001, at 1 (reporting that people of color were $9 \%$ of the California bar in 1991 and $17 \%$ in 2001).

21. Id.
22. Id
23. Id
24. Id


White twenty years from now. ${ }^{25}$ For Latinas/os, the gap between representation in the bar and in the general population is expected to grow even wider. $^{26}$

The current lack of diversity within the judiciary is due to a number of factors such as the pool of expericnced attorneys, political ties, access to networking, and career opportunities. First, of course, are historical patterns of discrimination within the educational system. Until the late 1960s, the number of minority lawyers and minority law students (particularly outside a handful of traditionally Black institutions) in the United States was insubstantial. ${ }^{27}$ Subsequent to the 1960 s, the number of attorneys of color has increased gradually as, at least until more recently, greater numbers of minorities graduated from law school.

For example, in 1970, African Americans, Latinas/os, Native Americans, and Asian Pacific Americans combined were only $2 \%$ of the lawyers in the United States. ${ }^{28}$ Among third-year law students enrolled at American Bar Association-accredited law schools in 1969-70 (the last class to be admitted largely before affirmative action), there were only 533 students of color in the nation, including only 42 Asian Pacific Americans. ${ }^{29}$ Due at least in part to affirmative action over the last three decades, there were 3,118 students of color in their third year of law school in 1981-82, 5,255 in $1991-92$, and 7,785 in 2001-02 (20\% of the total).$^{30}$ Even so, minorities comprised only $10 \%$ of the legal profession in 2000 , which trails the levels of diversity found in medicine and other professions. ${ }^{31}$

Thus, as measured by years of litigation experience, the pool of eligible candidates for the judiciary continues to be diminished by the residual effects of exclusionary patterns of the past. Although those numbers should improve as more recent law school graduates acquire the legal experience necessary to qualify them for the bench, the recent downturn in the

25. Id.

26. Id.

27. William C. Kidder, The Struggle for Access from Sweatt to Grutter: A History of African American, Latino, and American Indian Law School Admissions, I950-2000, 19 HARv. BLACKLETTER L.J. (forthcoming Spring 2003) (manuscript at 3-16, avallable at http://www.law.harvard.edu/ studorgs/blj/articles_folder/kidder.doc (last visited Feb. 24, 2003).

28. Univ. of Cal., Final Report of the Task Force on Graduate and Prof'l admissions, app.E, tbl. 3 (1977) (reporting U.S. census data).

29. I97I Survey of Minority Group Students in Legal Education, 24 J. Legal Educ. 487, 488 tbl.1 (1972). These 1969-70 figures were part of the first comprehensive survey of the law student population to report on Latinas/os, Native Americans, and Asian Pacific Americans.

30. Official aBA Guide to Approved Law Schools 200 Edition 455 (Rick L. Morgan \& Kurt Snyder eds., 2000) [hereinafter Law Schools 2001]; Official Guide to ABA-Approved Law ScHOOLS 2003 ED. 816 (Wendy Margolis et al. eds., 2002) [hereinafter LaW ScHOOLS 2003]. Partly, these figures reflect growth in legal education generally, as indicated by the growth in the number of law schools reporting data over this time: 144 (1969-70), 172 (1981-82), 176 (1991-92), and 184 (2001-02). LAW SCHOOLS 2001, supra, at 454; LAW SCHOOLS 2003, supra, at 816.

31. MiLES To Go 2000, supra note 9, at 18. 
proportion of underrepresented minorities enrolled in law school threatens the long-term outlook. ${ }^{32}$ Moreover, people of color and women still face considerablc difficulty gaining a foothold in the segments of the legal profession from which the judiciary traditionally draws its members. In 2002, only $16.3 \%$ of law firm partners were women, and $3.7 \%$ were minorities, including a range of only $2 \%$ to $7.3 \%$ minority partners in the cities of San Francisco, Los Angeles, Boston, Chicago, New York, Philadelphia, and Washington, D.C. ${ }^{33}$ In 1999, minorities were $9.1 \%$ of full professors at American law schools. ${ }^{34}$

The decline in racial diversity within our universities and law schools as a result of challenges and bans to affirmative action programs in several states threatens to exacerbate the situation. ${ }^{35}$ By the time this Speech goes to print, the Supreme Court will have ruled on the University of Michigan Law School's affirmative action program, undoubtedly with profound implications for law schools nationwide. ${ }^{36}$

In addition to the numbers themselves, it is important to recognize the forces at play in the actual selection process. Apart from the merit selection process formally applicable to some judges, such as federal magistrate and bankruptcy judges, Article III judges and most state court judges are appointed through the political process. In political appointments, a number of merit selection processes may be applied, including the screening of applicants by selection committees appointed by the president acting alone or with senators, and ratings by commissions such as the California Commission on Judicial Appointments ${ }^{37}$ or the American Bar

32. LAW SCHOOLS 2003, supra note 30, at 816 (indicating that the number of third-year students of color declined slightly between $1996-97$ and $2001-02$, from 7,869 to 7,785, even though the number of law schools increased from 179 to 184). Moreover, other research finds a widening disparity in admission rates between students of color and Whites across $A B A$-accredited schools since the mid1990s. Kidder, supra notc 27, manuscript at 45-49 charts 9-11; see also MiLEs to Go 2000, supra note 9 , at 1 ("Over the past five years minority law school enrollment has increased only 0.4 percent, the smallest five-ycar increase in 20 years.").

33. Nat'l Ass'n for law Placement, Women and Attorneys of Color at law Firms 2002, at http://www.nalp.org/nalpresearch/mw02sum.htm (last visited Feb. 24, 2003). For in-depth analysis of this issue, see, for example, Elizabcth Chambliss, Organizational Determinants of Law Firm Integration, 46 AM. U. L. REv. 669 (1997); David B. Wilkins \& G. Mitu Gulati, Why Are There So Few Black Lawyers in Corporate Law Firms? An Institutional Analysis, 84 CALIF. L. Rev. 493 (1996).

34. Miles to Go 200o, supra note 9, at 17,23 tbl.48. White women were $18.4 \%$ of full professors in 1998, and women of color were $2.9 \%$. Id at 23 tbl.49. For a comprehensive analysis of women law faculty at University of California law schools (Boalt Hall, Hastings, UCLA, and Davis), see Herma Hill Kay, UC's Women Law Faculty, 36 U.C. Davis L. Rev. 331 (2003).

35. See, e.g., Kidder, supra note 27, manuscript at 39-40 tbls.4-7 (documenting the decline in African American and Latina/o enrollment at Boalt Hall, UCLA, Davis, University of Washington, and University of Texas law schools since affirmative action was prohibited).

36. Grutter v. Bollinger, 288 F.3d 732 (6th Cir. 2002) (en banc), cert. granted, 123 S.Ct. 617 (Dec. 2, 2002).

37. Under CAL. CoNST. art. VI, § 16(d), the governor's appointments to the California Supreme Court and the Courts of Appeal are not final until confirmed by the Commission on Judicial 
Association.$^{38}$ It is, of course, in the nature of political appointments that a number of other factors may have significant bearing on the selection process, not the least of which are financial, social, and political ties to those in power. Many attorneys of color do not have equal access to those possessing influence in the selection process because of, for example, limited financial means, lack of social connections, not being in professional positions to command access to "connected" clientele, and so on, due in part to historical patterns of social exclusion, employment discrimination such as glass ceilings preventing minorities from reaching senior partner ranks, and economic inequities. Thus, progress in attaining diversity within the judiciary will likely be inhibited absent a conscious and concerted effort to break historical patterns and limit reliance on traditional networks in the selection process, which even if unintended have exclusionary effects. ${ }^{39}$ Moreover, such a conscious effort would encourage members of the bar from disadvantaged communities to aspire to and seek appointments to the bench.

Why should we be concerned with the lack of diversity within the judiciary? On a general level, diversity can be an important asset to virtually all institutions and agencies-governmental agencies, businesses, and nonprofit groups. It affects the direction and effectiveness of any organization by encouraging richer debate and more thoughtful reflection and discussions within the organization. Diversity facilitates the expansion of an organization's agenda and broadens its perspective. As Justice Powell reiterated in Regents of the University of California $v$. Bakke in the context of educational institutions:

[A] great deal of learning occurs informally. It occurs through interactions among students of both sexes; of different races, religions, and backgrounds; who come from cities and rural areas, from various states and countries; who have a wide variety of interests, talents, and perspectives; and who are able, directly or indirectly, to learn from their differences and to stimulate one another to reexamine even their most deeply held assumptions about

\footnotetext{
Appointments, which normally includes the Chief Justice, the Attorney General, and the senior presiding judge of the Court of Appeal in the affected appellate district. See California Commission on Judicial Appointments website, at http://www.courtinfo.ca.gov/courtadmin/otheragencies.htm (2003). In addition, there is a Judicial Nominees Evaluation Commission of the State Bar of California. This commission reviews the qualifications of cach nominee and makes a confidential recommendation to the governor. State Bar of California, The State Bar of California: What Does it Do? How Does it Work? 6 (2003), available at http://www.calbar.ca.gov/calbar/pdfs/whowhat I.pdf (last visited Mar. 26, 2003).

38. See, e.g., ABA Standing Comm. on Judicial Independence, Standards on State Judicial Selection, at http://www.abanet.org/judind/publ/reformat.pdf (July 2000).

39. Regarding the dangers of an "old boys club" in the merit selection process, see, for example, MILES To Go 2000, supra note 9, at 16 (quoting Judge Sidney A. Jones III regarding his experience in Illinois, where lawyers of color were completely excluded from the list of names forwarded to the president for nomination to the federal bench).
} 
themselves and their world. As a wise graduate of ours observed in commenting on this aspect of the educational process, 'People do not learn very much when they are surrounded only by the likes of themselves. ${ }^{40}$

During my sixteen years with the ACLU, 1 witnessed the salutary effect of diversity within the organization upon the level, quality, and sensitivity of internal debates on issues such as hate speech, affirmative action, and immigrants' rights. Diversity within the organization's staff has helped broaden its agenda to include, for example, the rights of women, gays and lesbians, and language minorities.

Diversity can establish the credibility of an institution, build bridges to other communities, and increase sensitivity to and awareness of diverse clientele and constituents. This is true whether the context is a union seeking to organize in a minority or immigrant community, a business looking to expand its markets to new communities, or a social service agency seeking to serve minority or culturally isolated populations.

Conversely, the lack of a diverse workforce limits an outfit's effectiveness. A further harm of segregation and underrepresentation is the perpetuation of detrimental stereotypes, continuing the myth that certain groups are inherently incapable of attaining certain accomplishments or performing certain jobs. It was not long ago that it would have been considered highly unusual to see a female physician, a Latina/o lawyer, an African American judge, or an Asian Pacific American sports figure. The visibility of diversity contributes to dispelling long-held stereotypes. ${ }^{41}$

At the same time, diversity provides role models for those historically excluded. It can provide a source of hope and inspiration for those who would otherwise limit their horizons and aspirations. ${ }^{42}$

40. Regents of the Univ. of Cal. v. Bakke, 438 U.S. 265, 312 n.48 (1978) (quoting President William Bowen of Princeton University). Bowen's comments about the educational benefits of diversity apply to Boalt Hall specifically. See Marjorie M. Shultz, Excellence Lost, 13 Berkeley WOMEN's L.J. 26 (1998) (describing, from first-hand experience, the importance of racial and ethnic diversity to the learning in law school classrooms). While Bowen's comments were based upon his expert judgment, there is now a fair amount of rigorous social science research on this question. See, e.g., Patricia Gurin et al., Diversity and Higher Education: Theory and Impact on Educational Outcomes, 72 Harv. Educ. Rev. 330 (2002) (analyzing data from the University of Michigan and the Cooperative Institution Research Program, and finding that diverse interaction in college produces both educational and civic benefits); William G. Bowen \& Derek BoK, The Shape of The River: LongTerm Consequences of Considering Race in College and University Admissions (1998) (studying elite colleges and universities).

41. See, e.g., Gabriel J. Chin et al., Beyond Self-Interest: Asian Pacific Americans Toward a Community of Justice, a Policy Analysis of Affirmative Action, 4 UCLA AsIAN PAC. AM. L.J. 129, 134 (1996) ("Affirmativc action also moderates outdated stereotypes by helping racial minorities achieve non-stereotypical positions of leadership and status. Seeing people of color in such unexpected positions-for example, an APA as a law professor, not an engineer-jars all of us, regardless of race, out of old habits of thought and expectation.") (footnote omitted).

42. For example, the presence of a few Asian Pacific American legal role models dedicated to serving the community, such as Justice Harry Low (then of the San Franciseo Supcrior Court, and later 
All of these considerations apply with as much force-if not moreto the judiciary. ${ }^{43}$ The case for diversity is especially compelling for the judiciary. It is the business of the courts, after all, to dispense justice fairly and administer the laws equally. It is the branch of government ultimately charged with safeguarding constitutional rights, particularly protecting the rights of vulnerable and disadvantaged minorities against encroachment by the majority. ${ }^{44}$ How can the public have confidence and trust in such an institution if it is segregated-if the communities it is supposed to protect are excluded from its ranks? ? $^{45}$

A diverse judiciary signals the public acknowledgment of historically excluded communities and sends an invaluable message of inclusion. It enhances courts' credibility among affected communities who would otherwise feel they have no voice within the institution. It helps dispel traditional stereotypes that Asian Pacific Americans and other minorities are not sufficiently intelligent, articulate, or decisive to be judges. And it assures students and young lawyers from historically underrepresented communities that they need not limit their aspirations.

Of course, as with any other institution, diversity also enhances the quality of judicial decision making. ${ }^{46}$ In addition to analyzing and applying the law, judges have to make determinations that draw. not so much upon legal acumen, but on an understanding of people and of human experiences. Such experiences inform assumptions that affect legal decisions. At trial and in evidentiary hearings, judges have to assess the credibility of witnesses. A witness' testimony may seem more credible if it is consistent

elevated to the California Court of Appeal for the First District) and Dale Minami (Boalt Hall class of 1971), had a profound impact by encouraging me and many of my peers to go to law school.

43. See Sherrilyn A. Ifill, Racial Diversity on the Bench: Beyond Role Models and Public Confidence, 57 WASH. \& LeE L. Rev. 405 (2000).

44. In a famous footnote in United States v. Carolene Products Co., 304 U.S. 144 (1938), Justice Stone, writing for the Court, articulated a classic basis for equal protection jurisprudence: "[P]rejudice against diserete and insular minorities may be a speeial condition, whieh tends seriously to curtail the operation of those political processes ordinarily to be relied upon to protect minorities, and which may eall for a correspondingly more searching judicial inquiry." Id. at $152 \mathrm{n.4}$; see also Chambers v. Florida, 309 U.S. 227, 241 (1940) ("Under our constitutional system, eourts stand against any winds that blow as havens of refuge for those who might otherwise suffer because they are helpless, weak, outnumbered, or because they are non-conforming victims of prejudice and public excitement.").

45. Professor Haney López, for example, has recently written about how fairness can be compromised by having judges nominate grand jurors from among their personal acquaintances. With an overwhelmingly White bench that nominates grand jurors from the nearly all-White inner circle of judges' friends, Latinas/os have been underrepresented in the pool of grand jurors in Los Angeles County. See Ian F. Haney Lópcz, Institutional Racism: Judicial Conduct and a New Theory of Racial Discrimination, 109 Y ALE L.J. 1717 (2000).

46. See 1fill, supra note 43, at $409-10$ ("[T]he most important benefit of judicial diversity is its potential to improve judicial decision-making."). 
with the judge's knowledge or experience, and, conversely, less credible if it remains outside the judge's experience. ${ }^{47}$

For example, it is commonly assumed within the legal profession that if a witness will not look you in the eye, he or she is untrustworthy.$^{48}$ But such an assumption may be blind to cultural differences. In some cultures, meeting the eyes of another is a sign of disrespect under certain circumstances. ${ }^{49}$ Averting eye contact in some culturcs may thus be a sign of

47. For example, in Hernandez v. New York, 500 U.S. 352 (1991), the Court held that the use of peremptory challenges to excludc Spanish speakers from jury duty did not violate the defendant's equal protection rights beeause the prosecutor provided a satisfactory race-neutral explanation. The prosecutor in the case explained that he "just felt from the hesitancy in [two Latina/o prospective jurors'] answers and their lack of eye contact" that the two potential jurors would not be able to accept the intcrpreter as the final arbiter of the witnesses' statements. Id. at $357 \mathrm{n}$. I. Justice Kcnnedy, writing for the plurality, found it significant that "the prosecutor did not rely on language ability without more, but explained that the specific rcsponses and the demeanor of the two individuals during voir dire caused him to doubt their ability to defer to the official translation of Spanish-language testimony." $I d$. at 360; see also id. at 375 ( $O^{\prime}$ Connor, J., concurring).

In this case, the prosecutor's asserted justification for striking certain Hispanic jurors was his uncertainty about the jurors' ability to accept the official translation of trial testimony. If this truly was the purpose of the strikes, they wcre not strikes beeause of race, and therefore did not violate the Equal Protection Clause....

Id.

Some scholars criticize the assumptions underlying the prosecutor's (and the Court's) views in Hernandez. See, e.g., Margarct E. Montoya, Silence and Silencing: Their Centripetal and Centrifugal Forces in Legal Communication, Pedagogy and Discourse, 5 Мich. J. RACE \& L. 847, 33 U. Mich. J.L. Reform 263 (2000). Professor Montoya rcviews several social science studies of nonverbal communication:

I argue that the prosccutor was interpreting the hesitancy on the part of the potential jurorstheir pausing before speaking, their silence-in a manner that was consistent with his worldview. Indeed, I think the prosecutor did not know enough about nonverbal communication, particularly cross-cultural communication, to understand that silencc, pauses, and hesitations are encoded with meaning in relation to the words and the language being spoken. 1 further assert that silence with its multiple meanings is an uncxplored aspect of linguistic diserimination.

Id. at 290. For gencral critiques of demcanor, see Jeffrey D. Smith, The Advocate's Use of Social Science Research into Nonverbal and Verbal Communication: Zealous Advocacy or Unethical Conduct? 134 MiL. L. Rev. 173 (199I); Olin Guy Wellborn IIl, Demeanor, 76 CoRnell L. Rev. 1075 (1991).

48. Robert M. Bastress \& Joseph D. Harbaugh, Interviewing, Counseling, and Negotiating: Skills for Effective Representation 139 (1990).

An inability by the client to sustain eye contact for more than a second or two at a time can also be informative. Client persistenee in glancing away from you immediately after making eye contact evidences nervousness or, possibly, deceit... A client who never, or almost never, looks at you indicates a severe state-perhaps a total breakdown in trust, an intense dislikc, extreme nervousness, psychiatric or physical illness, or some combination of these. Id.

49. See Paul R. Tremblay, Interviewing and Counseling Across Cultures: Heuristics and Biases, 9 CliniCal L. Rev. 373, 394 (2002) ("Eye contact patterns are also different in some Asian cultures, notably Japanese and Chinese, where avoiding eye contaet is eonsidered a sign of respcct, and in traditional Navajo society where eye contact is also deemed inappropriate.") (footnotc omitted); Sherene H. Razack, Looking White People in the Eye: Gender, Race, and Culture in Courtrooms and Classrooms 56-57, $72-75$ (1998) (citing examples, such as a Vietnamese doctor who would not make eye contact with a White patient when diseussing treatment risks, and explaining that in certain Aboriginal communities in northern Canada direct eye contact constitutes disrespect, but 
respect rather than untruthfulness. Diversity among those who must make these types of evaluations can significantly reduce occasions of crosscultural misunderstanding.

My own interactions with other judges reinforce the point. For example, a judge having to rule upon an issue of language barriers recalled witnessing as a child the ridicule inflicted upon his grandfather because of his limited English-speaking ability. That experience deepened his understanding of language discrimination and informed his approach to the issue.

Another time, an African American judge recalled for me an instance in which a White colleague of his presided over a racial harassment trial. The White judge apparently expressed incredulity as to the plaintiff's testimony regarding racist graffiti found on a locker, considering the plaintiff's descriptions of a drawing of a hangman's noose around a baboon inherently hard to believe, even though the plaintiff was otherwise credible. While his colleague found the allegations unbelievable, the African American judge recounted how members of his own family had experienced precisely the kinds of harassment described by the plaintiff. ${ }^{50}$

I have heard more than one judge remark about how a particular witness or litigant reminds them of a friend or relative, causing them to perhaps listen a bit more carefully or give pause before passing judgment on that person. It should not be surprising that one might tend to have an initial visceral, perhaps unconscious, sympathetic reaction to someone who strikes a chord of familiarity. ${ }^{51}$

I find that my own life experiences inform my understanding and perceptions of the world as a judge, whether I am evaluating evidence and

arguing that mere acknowledgment of cultural differences is inadequate to ensure faimess); Report of the Oregon Supreme Court Task Force on Racial/Ethnic Issues in the Judicial System, 73 OR. L. Rev. 823,861 (1994) ("A number of witnesses, for example, asserted that judges and juries are likely to draw adverse inferences from an Asian or Hispanic witness who fails to make eye contact with anyone in the courtroom, when that behavior may more accurately be seen as a cultural sign of respect.").

50. This anecdote is based on a personal conversation with a judge, so it would be inappropriate for me to disclose names.

51. There is a substantial body of social science research finding that unconscious racial identification and stereotyping is pervasive in American socicty even among people with egalitarian attitudes; in-group bias favoring those with whom one identifies, including subconscious identification along racial and ethnic lines, has been widely analyzed and measured. See, e.g., John F. Dovidio \& Samuel L. Gaertner, Aversive Racism and Selection Decisions: 1989 and 1999, 11 Psychol. SCI. 315 (2000); John F. Dovidio et al., Implicit and Explicit Prejudice and Interracial Interaction, $82 \mathrm{~J}$. Personality \& Soc. Psychol. 62 (2002); Allen R. McConnell \& Jill M. Leibold, Relations Among the Implicit Association Test, Discriminatory Behavior, and Explicit Measures of Racial Attitudes, $37 \mathrm{~J}$. Experimental Soc. Psychol. 435 (2001); Samuel R. Sommers \& Phoebe C. Ellsworth, White Juror Bias: An Investigation of Prejudice Against Black Defendants in the American Courtroom, 7 PsYCHOL. PuB. PoL'y \& L. 201 (2001); Steven J. Speneer et al., Automatic Activation of Stereotypes: The Role of Self-Image Threat, 24 Personality \& Soc. Psychol. Bull. 1139 (1998).

For a review and analysis of similar research findings, see, for example, Gary Blasi, Advocacy Against the Stereotype: Lessons from Cognitive Social Psychology, 49 UCLA L. REv. 1241 (2002); Linda Hamilton Krieger, The Content of Our Categories: A Cognitive Bias Approach to Discrimination and Equal Employment Opportunity, 47 STAN. L. REv. 1161 (1995). 
arguments on the bench or communicating with disputants as a settlement judge. For instance, having been a victim of a violent crime has given me invaluable insight into the outrage and anger of crime victims and the importance of delivering justice through the criminal process. Yet, having seen law enforcement excesses in my personal life and in the lives of the many clients I have served, I am sensitized to the need to examine closely, with a healthy skepticism, disputes over law enforcement conduct. Having managed and counseled small businesses, I understand the financial and emotional burden of meritless litigation, whether it involves a specious claim for breach of contract or an unwarranted claim of discrimination. Yet, as one who has experienced subtle and not-so-subtle forms of discrimination, I am sensitive to the humiliating and demoralizing effects of discrimination and the importance of having those claims fully and fairly evaluated. In short, my understandings and perceptions, and perhaps my subconscious predilections, are fashioned to a significant extent by my life experiences. And although a judge's duty is to recognize those predilections and control them, it is simply unrealistic to pretend that life experienccs do not affect one's perceptions in the process of judging.

Simply put, a judge's life experiences affect the willingness to credit testimony or understand the human impact of legal rules upon which the judge must decide. These determinations require a judge to draw upon something that is not found in the case reports that line the walls of our chambers. Rather judges draw upon the breadth and depth of their own life expcrience, upon the knowledge and understanding of peoplc, and of human nature. And inevitably, one's ethnic and racial background contributes to those life experiences.

A survey conducted a few years ago by the San Francisco Chronicle illustrates a deep dividc in how different racial groups experience and perceive discrimination. ${ }^{52}$ The San Francisco Chronicle reported that $43 \%$ of African Americans felt they had been treated unfairly by the police or court system, while only $3 \%$ of Whites felt that way. ${ }^{53} 44 \%$ of African Americans and $24 \%$ of Asian Pacific Americans felt they had been unfairly denied job opportunities, compared to $13 \%$ of Whites. ${ }^{54}$ As for the prevalence of discrimination, $45 \%$ of African Americans polled believed that African Americans experience a lot of prejudice, whereas only $27 \%$ of Whites agreed. ${ }^{55}$

Race matters whether we like it or not. In his seminal piece on unconscious racism, Professor Charles Lawrence describes his experience as a

52. See Clarence Johnson, Racism Still Real in Bay Area, S.F. Chron., Jan. 19, 1998, at Al (polling 1,000 Bay Area residents).

53. Id.

54. Id.

55. Id. 
five-year old sitting in a circle while his teacher reads "Little Black Sambo" and passes around the book's illustrations. ${ }^{56} \mathrm{He}$ describes the illustration of Little Black Sambo:

Little Black Sambo is running around a stack of pancakes with a tiger chasing him. He is very black and has a minstrel's white mouth. His hair is tied up in many pigtails, each pigtail tied with a different color ribbon. I have seen the picture before the book reaches my place in the circle. I have heard the teacher read the "comical" text describing Sambo's plight and have heard the laughter of my classmates. There is a knot in the pit of my stomach. I feel panic and shame. I do not have the words to articulate my feelings-words like "stereotype" and "stigma" that might help cathart the shame and place it outside of me where it began. But I am slowly realizing that, as the only black child in the circle, I have some kinship with the tragic and ugly hero of this story-that my classmates are laughing at me as well as at him. I wish I could laugh along with my friends. I wish I could disappear. ${ }^{57}$

Neither the teacher nor his classmates intended to be malicious or discriminatory. Still, Professor Lawrence's feelings were real and valid. Chances are the teacher and students were not conscious of the depth of the stereotype being perpetuated or of the hurt being inflicted. Professor Lawrence's childhood account says much about how deeply stereotypes are infected with race, affecting us consciously and subconsciously. It also says a lot about how life experiences, even at the age of five, can color our perceptions.

I too remember encountering the story of "Little Black Sambo" as a child in grade school. But in my memories, I was among the young students who laughed at the legend and illustrations with no awareness of the demeaning stereotype that was being perpetuated. And yet, though not perceiving myself as an outsider in that context, I have memories of childhood experiences in which I felt similarly marginalized: Being ridiculed on the schoolyard playground for my slanted eyes or my yellow skin; being the target of the all too familiar epithets "Chink" and "Chinaman," which dehumanized not only me as an individual, but also my family, my community, and my culture; living under the weight of Asian stereotypes of yellow-faced caricatures like Charlie Chan, Bonanza's houseboy Hop Sing, and $\mathrm{Fu}$ Man $\mathrm{Chu}$-caricatures that seemed to pervade comic books, movie

56. See Charles R. Lawrence III, The Id, the Ego, and Equal Protection: Reckoning with Unconscious Racism, 39 STAN. L. REv. 317, 317 (1987). Recently, Lawrence's article was accurately described as "one of the most influential Critical Race Theory articles ever written." Richard Delgado, Two Ways to Think About Race: Reflections on the Id, the Ego, and Other Reformist Theories of Equal Protection, 89 GEo. L.J. 2279, 2279 (2001).

57. Lawrence, supra note 56 , at 317. 
screens, and television shows; ${ }^{58}$ or, knowing that no matter how deep my roots are in this country, people who look like me continue to be stereotyped as the perpetual foreigner in the collective American Psyche-to this day, people comment about how surprisingly "American I sound" and ask "but where are you from 'originally'?"59

Despite these experiences, years passed before I came to understand the interconnectedness of my childhood experiences and those of Professor Lawrence, and how he must have felt sitting in that circle. Our views and perspectives are shaped by the roads on which we travel, roads that turn according to our individual and collective experiences, our senses of individual identity, and the communities with which we identify.

It is for this reason that the Constitution protects the goal that juries reflect a fair cross-section of the community ${ }^{60}$ Diversity can serve as an important structural safeguard against bias. It ensures a fuller, more thoughtful and balanced deliberation. For many of the same reasons, it is important that the judges who are called upon to pass judgment likewise reflect the broad human experiences that comprise all the communities we serve.

In this regard, Judge Harry T. Edwards of the D.C. Circuit recently observed:

Because of the long history of racial discrimination and segregation in American society, it is safe to assume that a disproportionate number of blacks grow up with a heightened awareness of the problems that pertain to [equal opportunity and discrimination, standing, and criminal law]. Of course, not all blacks have the same exposure to these problems, in part because class, not merely raee, affects one's exposure. And not all blacks share the same views on

58. On the depiction of Asian Pacific Americans in the movics and the larger consequences of stereotyping, sce Keith Aoki, Is Chan Still Missing? An Essay About the Film Snow Falling on Cedars and Representations of Asian Americans in U.S. Films, 7 UCLA ASIAN PAC. AM. L.J. 30 (2001); Sumi K. Cho, Converging Stereotypes in Racialized Sexual Harassment: Where the Model Minority Meets Suzie Wong, 1 J. Gender Race \& Just. 177 (1997).

59. According to a poll conducted by the Los Angeles Times in the mid-1990s, for example, $32 \%$ of Whitcs, $42 \%$ of African Americans, and 37\% of Latinas/os consider Asian Americans "perpetual foreigners." See llhyung Lee, Race Consciousness and Minority Scholars, 33 ConN. L. Rev. 535, 56667 (2001) (citing Taeku Lee, Racial Attitudes and the Color Line(s) at the Close of the Twentieth Century, in The State of asian Pacific america: Transforming Race Relations 103, 128 (Paul M. Ong ed., 2000)); see also Frank H. Wu, The Profiling of Threat Versus the Threat of Profiling, 7 Mich. J. RACE \& L. 135, 142-43 (2001) (describing his repeated personal encounters with the perpetual foreigner stereotype).

60. See Lockhart v. McCree, 476 U.S. 162 (1986) (fair cross-section requirement does not prevent prosecutor from removing for cause jurors whose opposition to the death penalty is so strong that it would impair the performance of their duties as jurors); Taylor v. Louisiana, 419 U.S. 522 (1975) (where $53 \%$ of eligible jurors were women and jury service system eaused only $10 \%$ of the people on the jury wheel to be women, fair cross-section requirement was violated); cf. Batson v. Kentucky, 476 U.S. 79 (1986) (establishing the evidentiary requirements for prima facie case of intentional racial discrimination based on evidence of prosecutor's exercise of peremptory challenges). 
the solutions to the problems. But, just as most of my Jewish colleagues have more than a fleeting understanding of antiSemitism, the Holocaust, and issues surrounding Israel and Palestine, most blacks have more than a fleeting understanding of the effects of racial discrimination. ${ }^{61}$

Judge Edwards concludes:

[I]t is inevitable that judges' different professional and life experiences have some bearing on how they confront various problems that come before them. And in a judicial environment in which collegial deliberations are fostered, diversity among the judges makes for better-informed discussion. It provides for constant input from judges who have seen different kinds of problems in their pre-judicial careers, and have sometimes seen the same problems from different angles. A deliberative process enhanced by collegiality and a broad range of perspectives necessarily results in better and more nuanced opinions-opinions which, while remaining true to the rule of law, over time allow for a fuller and richer evolution of the law. ${ }^{62}$

The practical value of diversity within the judiciary is illustrated by Justice O'Connor's 1992 tribute to Justice Thurgood Marshall. ${ }^{63}$ She recounted Justice Marshall's fondness for sharing personal stories with the other justices in conference in order to emphasize legal points, including stories about $\mathrm{Ku}$ Klux Klan violence, jury bias, defending an innocent African American wrongly convicted of rape and sentenced to death, and the many indignities of racial segregation he personally had endured. ${ }^{64}$ Justice O'Connor spoke about the impact those stories, told by a man who had traveled a very different path than her, had on her own understanding of the issues confronting the Court. She spoke about the impact of legal rules on human lives, and the need for judges to strive to narrow the gap between the ideal of equal justice and the reality of social inequality:

No one could help but be moved by Justice Thurgood Marshall's spirit; no one could avoid being touched by his soul. ... Occasionally, at Conference meetings, I still catch myself looking expectantly for his raised brow and his twinkling eye,

61. Harry T. Edwards, Race and the Judiciary, 20 YALE L. \& PoL'y Rev. 325, 328 (2002).

62. Id. at 329. While Judge Edwards's observations could be construed as focusing primarily upon appellate judges, his remarks carry powerful force as applied to trial court judges as well, even though they generally do not sit as panels or as a full court. There is a great deal of informal interchange amongst trial judges and other judges through, for example, committec work, participation in educational programs and conferences, lunch room or hallway conversations, or simply the natural social interaction of colleagues.

63. See Sandra Day O'Connor, Thurgood Marshall: The Influence of a Raconteur, 44 STAN. L. Rev. 1217 (1992).

64. See id. at 1218-19. 
hoping to hear, just once more, another story that would, by and by, perhaps change the way I see the world..$^{65}$

Justice Marshall's contribution to the Court was not only as a compassionate jurist, but also as a person who touched the soul of others with his humanity. Marshall is an enduring testament to the value-to the necessity—of diversity in the judiciary. ${ }^{66}$

In summary, diversity invigorates the judiciary. Chief Justice Roger Traynor of the California Supreme Court once described the courthouse as "[e]very man's castle. His fortress against tyrants of powerful government or of powerful private groups, and against mobs and brutes and scoundrels.... [J]ustice you find and share with others in every man's castle, the courthouse." ${ }^{67}$ Without diversity, Justice Traynor's vision of the courthouse's role in American democracy becomes elusive. ${ }^{68}$ With diversity, the power of the judiciary to protect more fully and effectively all of our constitutional rights becomes that much more complete.

65. Id. at 1220

66. The value of diversity in the judiciary transcends any particular political and philosophical leaning. Racial experience can matter irrespective of such leanings. A vivid recent cxample is Virginia v. Black, $123 \mathrm{~S}$. Ct. 1536 (2003), in which the Court held that a state may outlaw cross burning carried out with the intent to intimidate without violating the First Amendment. While the Court's ruling in Black was quitc fractured, by all accounts, Justice Thomas' impassioned description of cross burning as part of a "reign of terror" had a profound impact on the tone of oral argument. See Paul Brest, Diversity Gives Depth to the Law, L.A. Times, Jan. 3, 2003, at B13 ("While most white members of the Supreme Court understand the message conveyed by cross burning, reports of the recent oral argument in the cross-buming case suggest that the justices were given a new perspective after listening to Justice Clarence Thomas' passionate description from the bench."); see also Linda Greenhouse, Cross Burnings is Terror, Milwaukee J. Sentinel, Dec. 12, 2002, at Al (observing that the other justices gave Thomas "rapt attention. Afterward, the court's mood appeared to have changed.").

67. A Celebration Honoring James R. Browning, Chief Judge Emeritus, On the Fortieth Anniversary of His Appointment to the Ninth Circuit Court of Appeals, 63 MoNT. L. REv. 251, 276 (2002) (Judge Browning quoting Justice Traynor). Before serving on the California Supreme Court for three decades, Traynor was a dean and professor at Boalt Hall. See Adrian A. Kragen, A Legacy of Accomplishment, 71 CALif, L. Rev. 1055, 1055-57 (1983).

68. See A. Leon Higginbotham, Jr., Seeking Pluralism in Judicial Systems: The American Experience and the South African Challenge, 42 DukE L.J. 1028, 1041 (1993) ("The danger of a homogenous court is that there is no 'outsider' within the court to challenge the biases the dominant group accepts as 'self-evident' truths."). 